\title{
Accelerated aging of onion seeds (Allium cepa L.) submitted to saturated salt solution
}

\author{
Envejecimiento acelerado de semillas de cebolla \\ (Allium cepa L.) sometidas a soluciones salinas saturadas
}

LILIAN MADRUGA DE TUNES ${ }^{1}$

LIZANDRO CICILIANO TAVARES ${ }^{2}$

CASSYO DE ARAÚJO RUFINO ${ }^{2}$

JUCILAYNE FERNANDES VIEIRA ${ }^{2,3}$

TANIZE DOS SANTOS ACUNHA ${ }^{2}$

ANTONIO CARLOS SOUZA ALBUOUEROUE BARROS ${ }^{2}$

MARLOVE FÁTIMA BRIÃO MUNIZ ${ }^{1}$
Campo de producción de semillas de cebolla.

Foto: Akatu Produção de Sementes Ltda.

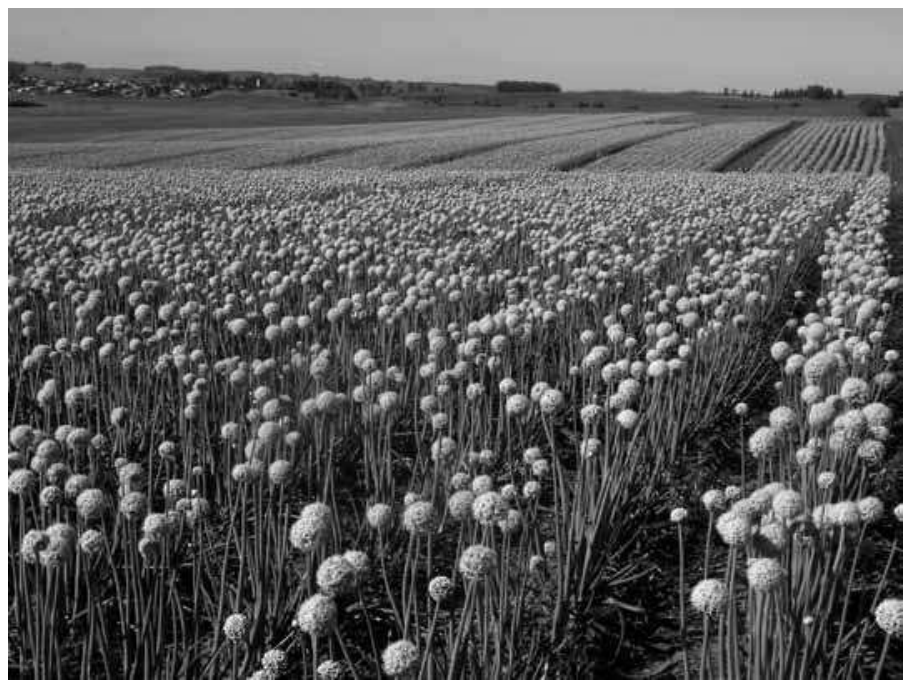

\begin{abstract}
The objective of the present study was to evaluate the methodology of the accelerated aging test to evaluate the physiological potential of onion seeds, as well as verify the possibility of using unsaturated and saturated solutions of sodium chloride $(\mathrm{NaCl})$ as an option for water uptake control in seeds during the test without reducing sensitivity. Five lots of onion seeds were tested for germination, seedling emergence, emergence speed and accelerated aging (periods of $24,48,72$, or 96 hours, with or without the use of a saturated saline solution of $\mathrm{NaCl}$ ). The use of unsaturated and saturated solutions of $\mathrm{NaCl}$ reduced water absorption by onion seeds during the accelerated aging test, resulting in a less pronounced rate of deterioration, and less drastic and more uniform results. The 48 hour treatment with unsaturated and saturated $\mathrm{NaCl}$ solutions is an option for use because it promotes a better classification of the onion seed lots at different vigor levels.
\end{abstract}

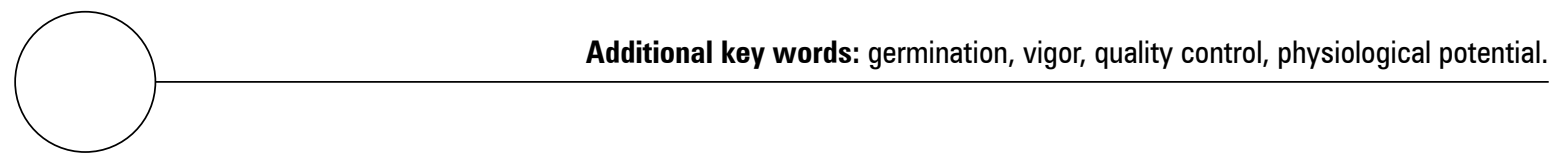

Federal University of Santa Maria (UFSM), 97105-900, Santa Maria, RS (Brazil).

Federal University of Pelotas (UFPel), Pelotas, RS (Brazil).

Corresponding author. laynevieira@yahoo.com.br 


\section{RESUMEN}

El objetivo del presente estudio fue evaluar la metodología del test de envejecimiento acelerado para evaluar el potencial fisiológico de las semillas de cebolla, también verificar la posibilidad de usar soluciones de cloruro de sodio $(\mathrm{NaCl})$ saturadas e insaturadas como una opción para controlar la absorción de agua de las semillas durante el test sin reducir su sensibilidad. En cinco lotes de semillas de cebolla sometidos a tratamientos de envejecimiento acelerado (periodos de 24, 48, 72 o 96 horas, con o sin el uso de soluciones saturadas de $\mathrm{NaCl}$ ) se evaluó la germinación, emergencia de plántulas y la velocidad de emergencia. El uso de soluciones saturadas e insaturadas de $\mathrm{NaCl}$ redujo la absorción de agua por las semillas de cebolla durante el test de envejecimiento acelerado, dando como resultado una tasa de deterioro menos pronunciada y resultados menos drásticos y más uniformes. El tratamiento de 48 horas con soluciones insaturadas y saturadas de $\mathrm{NaCl}$ es una opción para usar, ya que promueve una mejor clasificación de los lotes de semillas de cebolla en diferentes niveles de vigor.

Palabras clave adicionales: germinación, vigor, control de calidad, potencial fisiológico.

Fecha de recepción: 27-01-2011

Aprobado para publicación: 21-11-2011

INTRODUCTION

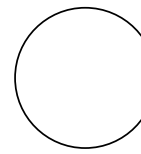

Cultivation of vegetables is carried out in intensive production systems and the success of this activity depends on the use of the seed, which hopefully germinates quickly and evenly. On the other hand, high physiological potential is responsible for the performance of seeds in the field and may even reflect the productivity of various species (Rodo, 2002).

Onion (Allium cepa L.) is an important crop in most parts of the world and onion seeds have a high commercial value and the availability of satisfactory vigor tests for onion seeds is desirable (Rodo and Marcos Filho, 2003). Thus, the fundamental importance of seed vigor during crop establishment in the field with more vigorous lots creating more uniform emergence is widely recognized (Rodo, 2002).

The accelerated aging test is one of the best known for the vigor of seeds of many cultivated species. This test is able to provide information with a high degree of consistency (Hampton and Tekrony, 1995; Rodo et al., 2000; Rodo and
Marcos Filho, 2003). This test assesses the response of seeds through germination tests, after they have been subjected to high temperature and relative humidity near $100 \%$ for some period of exposure (Torres, 2005).

This test is based on the fact that the deterioration rate increases considerably when seeds are exposed to these conditions (Hampton and Tekrony, 1995). Thus, it is noticed that, in lots of seeds with low vigor, there is a greater decrease in viability after exposure to stressful situations by aging (Marcos Filho, 1999a). Therefore, it is possible to establish differences in the physiological potential of these lots (Panobianco and Marcos Filho, 2001). An important aspect to be considered in the accelerated aging test is the difference in water uptake by seeds because, when they are exposed to a humid atmosphere, a sharp change in the moisture content may occur. Some studies carried out with species that have seeds of small size have revealed inconsistent results due to the very sharp variation in moisture content of the samples after aging (Ramos et al., 2004). 
Thereby, some alternatives have been studied for conducting the accelerated aging test with seeds of these species, such as the use of water instead of salt solutions. Depending on the solution used, specific levels of relative humidity are obtained; which permits a reduction in the rate of water absorption, and speed and intensity of deterioration of seeds (Jianhua and McDonald, 1996), without reducing the sensitivity of the test. Thus, the objectives of this research were: to study the methodology of the accelerated aging test to evaluate the physiological potential of onion seeds, and to verify the possibility of the use of unsaturated and saturated solutions of $\mathrm{NaCl}$ as an alternative to control water uptake by seeds during testing.

\section{MATERIAL AND METHODS}

The research was conducted at the Seed Analysis Laboratory, Department of Plant Science, Federal University of Pelotas, Brazil. Five seed lots of the onion (L1, L2, L3, L4 and L5) cultivar 'Primavera' were used. The performance of each lot was measured by the following tests:

The water content (TA) was measured using $3 \mathrm{~g}$ of seeds per subsample. The seeds were weighed and taken to an oven, $105^{\circ} \mathrm{C}\left( \pm 3^{\circ} \mathrm{C}\right)$ for $24 \mathrm{~h}$ (Ministry of Agriculture, Livestock and Food Supply, 2009).

Germination was measured by placing four replicates of 100 seeds, on a double layer of filter paper in a plastic Petri dish (90 $\mathrm{mm}$ in diameter), moistened with distilled water, equivalent to 2.5 times the mass of the dry paper. The plastic Petri were kept in an incubator $\left(20^{\circ} \mathrm{C}\right)$. The counts were performed at 7 and $12 \mathrm{~d}$ after incubation. This was done in accordance with the Seed Analysis Rules (Ministry of Agriculture, Livestock and Food Supply, 2009). The results were expressed as percentage of normal seedlings.

Seedling emergence (SE) was determined by sampling four replicates of 50 seeds per lot. The- se were placed to germinate in plastic trays containing sand and kept at a temperature of $20^{\circ} \mathrm{C}$ at room-conditions. Irrigation was done whenever necessary, and the evaluation was assessed $16 \mathrm{~d}$ after sowing, when emergence ceased. The final germination percentage of normal seedlings was calculated (Nakagawa, 1999).

Emergence speed index (ESI): This test was carried out in conjunction with the test of seedling emergence. The number of emerged seedlings was counted daily (seedling length of $0.5 \mathrm{~cm}$ above substrate) until the sixteenth day. For each replication, the emergence speed index was calculated adding the number of emerged plants each day, divided by the number of days from sowing, according to Maguire (1962), by the formula:

$$
E S I=\frac{E_{1}}{N_{1}}+\frac{E_{2}}{N_{2}}+\ldots+\frac{E n}{N n}
$$

where: $E S I=$ emergence speed index, $E 1, E 2, E n$ $=$ number of seedlings emerged, computed at the first, second and last count, $N 1, N 2, N n=$ number of days from sowing to first, second and final count.

Accelerated aging test (traditional), the seeds, after being weighed $(1.0 \mathrm{~g})$, were distributed forming a uniform layer on an aluminum mesh tray, in a plastic Petri dish containing $40 \mathrm{~mL}$ distilled water at the bottom. The Petri dish was kept in an incubator adjusted to $42^{\circ} \mathrm{C}$ for 24 , 48, 72 and $96 \mathrm{~h}$. After each aging period, four subsamples of 100 seeds were submitted to germination tests, following the method described above, a single assessment was conducted on the sixth day after sowing. The water content of the seeds (described above) was determined after each aging period to verify the uniformity of test conditions (Marcos Filho, 1999b).

Accelerated aging with the use of a non-saturated solution of $\mathrm{NaCl}$ (SNS) was carried out similar to accelerated aging. Forty $\mathrm{mL}$ of unsaturated salt solution (11 g NaCl dissolved in $100 \mathrm{~mL}$ water) were added to the Petri dishes, establishing an 
environment with approximately $94 \%$ relative humidity. This test was an adaptation from the methodology described by Jianhua and McDonald (1996) and Salisbury and Ross (1992).

Accelerated aging with the use of a saturated $\mathrm{NaCl}$ solution (SSS) was performed similarly to a traditional accelerated aging test. In addition, $40 \mathrm{~mL}$ of saturated $\mathrm{NaCl}$ solution $(40 \mathrm{~g} \mathrm{NaCl}$ dissolved in $100 \mathrm{~mL}$ water) were added to the Petri dish, establishing an environment with approximately $76 \%$ relative humidity. This was done following the methodology described by Jianhua and McDonald (1996).

The experiment was carried out according to a completely randomized design with a $4 \times 5$ factorial arrangement (four times of exposure and five lots of seeds). Statistical analysis was not performed for water content. The data obtained were subjected to variance analysis and the statistical averages were compared with the Tukey test, with the level of significance set at $5 \%$. As such, the analysis was performed with the software SISVAR (Ferreira, 2000)

\section{RESULTS AND DISCUSSION}

The moisture content of the onion seeds was similar for the five lots, these values showed humidity between 6.09 and $7.01 \%$ (table 1). This fact is important for the evaluations of accelerated aging, considering that the uniformity of water content of seeds is essential for the standardization of the assessment and obtaining consistent results (Marcos Filho, 2005). It is important because seeds that are more humid are more affected by accelerated aging. According to Tunes et al. (2011), when water content of seeds is relatively low, as occurred in the lots of onion seeds, greater reliability is achieved for the results obtained in tests of seed quality.

Significant interactions between the four times of exposure and five lots of seeds were not ob-

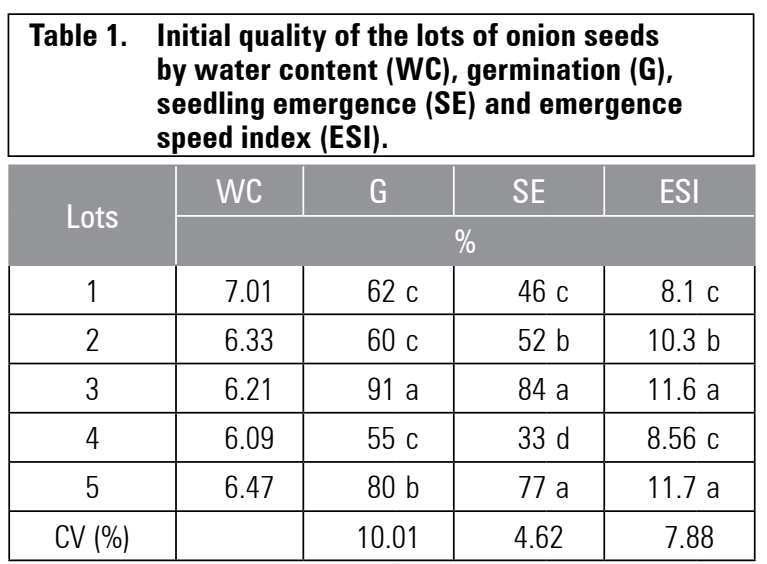

Means followed by the same letter in the column do not differ by the Tukey test $(P \leq 0.05 \%)$.

served. The results of the germination test (table 1) indicated differences between the seed lots of onion, especially lot 3 with superior quality, lots 1,2 and 4 of lower quality, and lot 5 of intermediate quality. The test of emergence distinguished all the lots, showing lots 3 and 5 as a potential physiological top, followed by lots 2,4 and 1 in descending order of quality. The emergence speed index test differentiated only lots 3 and 5 , which were of higher quality when compared to the others. The disagreement between the results obtained in these test suggests the necessity of a higher number of tests before classifying lots based on the physiological potential, because every test has a different principle and provides additional information for the decision about the final use of each seed lot.

The results of accelerated aging (table 2) showed that the following test allowed stratification of the seed lots of onion: the traditional procedure $(72 \mathrm{~h})$, with the use of a non-saturated solution of $\mathrm{NaCl}(48$ and $72 \mathrm{~h}$ ) and with the use of a saturated $\mathrm{NaCl}$ solution ( $48 \mathrm{~h}$ ). These tests provided the same separation of the lots found by the emergence of seedlings (table 1) (different vigor tests with the same rank). The addition of $\mathrm{NaCl}$ prevents the seeds from absorbing much water (provides a lower relative humidity when compared with only water). In this case, the seeds suffered a sharp deterioration process, while 


\begin{tabular}{|c|c|c|c|c|c|c|c|c|c|c|c|}
\hline Table 2. Percentage of germination of onion seeds after the traditional accelerated aging test $\left(\mathbf{H}_{\mathbf{2}} \mathbf{0}\right)$, non-saturated \\
solution (SNS) and saturated NaCl solution (SSS) during the exposure periods of 24, 48, 72 and 96 h. \\
\hline
\end{tabular}

Means followed by the same letter in the column do not differ by the Tukey test $(P \leq 0.05 \%)$.

they are exposed to a method that causes stress on seeds with the use of high temperature.

However, when the values of germination were analyzed after traditional aging a reduction in the percentage of normal seedlings was noted, which indicates that the procedure using $72 \mathrm{~h}$ of exposure was not the most suitable for onion seeds. Similar results were obtained by Ramos et al. (2004), Tunes et al. $(2009,2011)$ in seeds of rocket, and barley and ryegrass, respectively. They found that the stress caused by the accelerated aging test for a period of $72 \mathrm{~h}$ caused significant reduction in the germination of the seeds.

The best solution is to use the period of $48 \mathrm{~h}$ exposure for seeds with a non-saturated solution of $\mathrm{NaCl}$ or $48 \mathrm{~h}$ in a saturated $\mathrm{NaCl}$ solution, because the shortest period of execution is a desirable feature in a test of vigor, allowing energy savings in the use of equipment. In addition, it permits obtaining results in a short period of time.

The average results of the water content after the accelerated aging test, unsaturated and saturated solution of $\mathrm{NaCl}$ are shown in table 3. It may be observed that the onion seeds aging in the traditional procedure showed higher levels of water and with larger variations, differing values of up to 8.5 percentage points (pp), which exceed the tolerable limits of 3 to 4 pp indicated by Marcos Filho (1999b). In the traditional procedure, the seeds absorbed a higher percentage of water compared to those using the methodology of unsaturated and saturated solutions of $\mathrm{NaCl}$. Similarly, Rodo et al. (2000) found for carrot seeds, variations from 5.0 to 9.2 percentage points, which is considered excessive, at the end of an accelerated aging test.

Table 3. Water content (WC) from onion seeds after the traditional accelerated aging test $\left(\mathrm{H}_{2} \mathrm{O}\right)$, non-saturated solution (SNS) and saturated NaCl solution (SSS) during the exposure period of 24, 48, 72 and $96 \mathrm{~h}$.

\begin{tabular}{|c|c|c|c|c|c|c|c|c|c|c|c|c|}
\hline \multirow{3}{*}{ Lots } & \multicolumn{4}{|c|}{ Traditional } & \multicolumn{4}{|c|}{ SNS } & \multicolumn{4}{|c|}{ SSS } \\
\hline & $24 \mathrm{~h}$ & $48 \mathrm{~h}$ & $72 \mathrm{~h}$ & $96 \mathrm{~h}$ & $24 \mathrm{~h}$ & $48 \mathrm{~h}$ & $72 \mathrm{~h}$ & $96 \mathrm{~h}$ & $24 \mathrm{~h}$ & $48 \mathrm{~h}$ & $72 \mathrm{~h}$ & $96 \mathrm{~h}$ \\
\hline & \\
\hline 1 & 8,11 & 13,02 & 25,44 & 40,27 & 7,36 & 14,22 & 14,35 & 16,21 & 7,03 & 11,03 & 14,31 & 14,02 \\
\hline 2 & 7,54 & 15,16 & 22,07 & 36,10 & 6,91 & 13,77 & 13,15 & 15,91 & 7,13 & 12,29 & 12,88 & 13,61 \\
\hline 3 & 7,09 & 15,01 & 19,11 & 31,82 & 6,75 & 10,95 & 9,44 & 12,51 & 6,16 & 9,47 & 11,45 & 12,48 \\
\hline 4 & 9,21 & 17,82 & 28,15 & 40,19 & 8,05 & 14,67 & 14,66 & 15,26 & 6,33 & 12,03 & 11,66 & 14,26 \\
\hline 5 & 7,32 & 14,63 & 20,35 & 31,78 & 7,02 & 11,08 & 10,23 & 13,19 & 6,49 & 10,03 & 11,39 & 11,33 \\
\hline
\end{tabular}


On the other hand, it was found that the use of a saturated saline solution reduced the rate of water uptake by seeds during the aging period, not exceeding the range of water content between aged lots. The conditions of accelerated aging with unsaturated and saturated $\mathrm{NaCl}$ promoted less drastic effects because they included lower water content (up to $16.21 \%$ [SNS] and $14.26 \%$ [SSS], while the traditional showed $40.27 \%$ ). The deterioration of the seeds was reduced compared to the traditional method. This was also observed by Torres and Marcos Filho (2003), when they worked with melon seeds.

Similar results were found by Torres (2004), with the use of saturated salt accelerated aging test with anise seeds, where the slowing of water absorption by seeds caused less pronounced deterioration and less drastic and more uniform results than those obtained with the traditional procedure. This method was efficient for vigor evaluation of watermelon seeds (Citrullus lanatus) (Bhering et al., 2003), tomato (Solanum lycopersicum) (Panobianco and Marcos Filho, 2001), rocket (Eruca sativa) (Ramos et al., 2004), barley (Hordeum vulgare) (Tunes et al., 2009) and ryegrass (Lolium multiflorum) (Tunes et al., 2011).

These results confirm that the use of saturated or unsaturated $\mathrm{NaCl}$ contributes to the improvement of the methodology of the accelerated aging test in evaluating the vigor of onion seeds, because, besides using the same equipment of the traditional procedure, it provides conditions to decrease water absorption by seeds and more even results.

\section{CONCLUSION}

The use of unsaturated and saturated solutions of $\mathrm{NaCl}$ decreased water absorption and the rate of deterioration of onion seeds during accelerated aging. The procedure using $48 \mathrm{~h}$ with no solution saturated $\mathrm{NaCl}$ (SNS) or saturated (SSS) is an option to be used because it promotes a better classification of the seed lots of onion at different vigor levels.

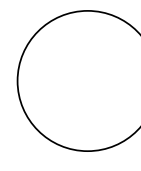

Bhering, M.C., D.C.F.S. Dias, D.I Barros, and D. Tokuhisa. 2003. Evaluation of the vigor on watermelon seeds (Citrullus lanatus Scherad.) by the accelerated aging test. Rev. Bras. Sem. 25, 1-6.

Ferreira, D.F. 2000. SISVAR statistics analyses- Windows version 4.0. pp. 225-258. In: Anais Reunião Anual da Região Brasileira da Sociedade Internacional de Biometria. UFSCAR, São Carlos, SP, Brazil.

Hampton, J.G. and D.M. Tekrony. 1995. Handbook of vigour test methods. $3^{\text {th }}$ ed. ISTA, Zurich.

Jianhua, Z. and M.B. McDonald. 1996. The saturated salt accelerated aging test for small-seeded crops. Seed Sci. Technol. 25, 123-131.

Maguire, J.D. 1962. Speed of germination-aid in selection and evaluation for seedling emergence and vigour. Crop Sci. 2, 176-177.

\section{BIBLIOGRAPHIC REFERENCES}

Marcos Filho, J. 1999a. Accelerated aging test. In: Krzyzanowski, F.C., R.D. Vieira, and J. B. França (eds.). Seed vigor. Concepts and testing. Abrates, Londrina, Brazil.

Marcos Filho, J. 1999b. Vigor tests. Importance and use. In: Krzyzanowski, F.C., R.D. Vieira, and J. B. França (eds.). Seed vigor. Concepts and testing. Abrates, Londrina, Brazil.

Marcos Filho, J. 2005. Seed physiology of cultivated plants. FEALO, Piracicaba, SP, Brazil.

Ministry of Agriculture, Livestock and Food Supply. 2009. In: Brazilian rules for seed testing. In: http:// www.agricultura.gov.br/arq_editor/file/2946_regra_analise_sementes.pdf 2009. 395p; access: December, 2010 .

Nakagawa, J. 1999. Vigor tests based on seedlings performance. In: Krzyzanowski, F.C., R.D. Vieira, and 
J.B. França (eds.). Seed vigor. Concepts and testing. Abrates, Londrina, Brazil.

Panobianco, M. and J. Marcos Filho. 2001. Accelerated aging and controlled deterioration of tomato seeds. Sci. Agric. 58, 525-531.

Ramos, N.P., E.P.O. Flor, E.A.F. Mendonça, and K. Minami. 2004. Accelerated aging of Eruca sativa L. seeds. Rev. Bras. Sem. 26, 98-103.

Rodo, A.B. 2002. Physiological potential evaluation of onion seeds and its relation to field plant performance. Ph.D. thesis. São Paulo University, Piracicaba, Brasil.

Rodo, A. B. and J. Marcos-Filho. 2003. Onion seed vigor in relation to plant growth and yield. Hortic. Bras. $21,220-226$.

Rodo, A.B., M. Panobianco, and J. Marcos Filho. 2000. Alternative methodology for the accelerated aging test for carrot seeds. Sci. Agric. 57, 289-292.
Salisbury, F.B. and C.W. Ross. 1992. Plant physiology. $4^{\text {th }}$ ed. Wadsworth Inc., Belmont, CA.

Torres, S.B. 2004. Accelerated aging test on anise seeds. Braz. J. Seeds 26, 20-24.

Torres, S.B. and J. Marcos Filho. 2003. Accelerated aging of melon seeds. Sci. Agric. 60, 77-82.

Torres, S.B. 2005. Envelhecimento acelerado em sementes de pepino com e sem solução salina saturada. Hortic. Bras. 23, 303-306.

Tunes, L.M., P.G Badinelli, F. Olivo, and A.C.S.A. Barros. 2009. Accelerated aging test in Barley seeds. Magistra $21,111-119$.

Tunes, L.M., D.C. Pedroso, P.G. Badinelli, L.C. Tavares, C.A. Rufino, A.C.S.A. Barros, and M.F.B. Muniz. 2011. Accelerated aging of ryegrass seeds submitted to saturated salt solution. Ciência Rural 41, 33-37. 